Volume 1 Issue 2, July-December: pp.107-118.

Faculty of Law, Universitas Lampung, Bandar Lampung, Indonesia. http://jurnal.fh.unila.ac.id/index.php/ip

\title{
Kebijakan Penanggulangan Praktek Mafia Peradilan di Lingkungan Mahkamah Agung
}

\section{Policies to Overcome Judicial Mafia Practices within the Supreme Court}

\author{
Irhamy Tauhid \\ irhamytauhid99@gmail.com \\ Lembaga Konsultasi dan Bantuan Hukum-Serikat Pekerja Seluruh Indonesia
}

Submitted: August 3, 2020; Reviewed: August 18, 2020; Accepted: Sep 17, 2020

\section{Info Artikel}

\section{Abstrak}

Kata Kunci: Kebijakan; Mafia
Peradilan; Mahkamah Agung.
Keywords: Policy; Judicial Mafia;
Supreme Court.

DOI:

https://doi.org/10.25041/ip.v1i2.2051.

\begin{abstract}
Fenomena adanya jual beli perkara di lingkungan peradilan memang masih menjadi isu tabu bagi masyarakat, hal ini dikarenakan rapihnya permainan para oknum tersebut sehingga sulit untuk dibuktikan. Sehingga orang menyebutnya sebagai praktik mafia peradian. Studi ini akan fokus pada tiga permasalahan hukum yaitu menganalisa bagaimanakah kebijakan di Mahkamah Agung dalam pemberantasan praktek mafia peradilan di lingkungan pengadilan, mengapa terjadi hambatan peran badan pengawas mahkamah agung dalam mewujudkan pemberantasan praktek mafia peradilan di lingkungan pengadilan, bagaimana kebijakan ideal badan pengawas mahkamah agung dalam memberantas praktek mafia peradilan Penelitian ini menggunakan pendekatan Yuridis Normatif dan Empiris. Penelitian normatif dilakukan terhadap hal-hal yang bersifat teoritis asas-asas hukum, sedangkan pendekatan empiris yaitu dilakukan untuk mempelajari hukum dalam kenyataannya dilapangan. Adapun hasil penelitian yang didapatkan bahwa salah satu wujud dari upaya kebijakan kriminal dalam
\end{abstract}


menanggulangi praktek mafia peradilan di lingkungan pengadilan dengan cara membangun karakteristik sumber daya manusia instument pelaksana peradilan yang mencakup Hakim dan juga Panitera agar menjadi aparatur yang bebas dari korupsi melalui dibuktikan dengan diikutsertakan melalui sosialisasi, bimbingan teknis dan juga studi banding ke negara yang mempunyai tekad memberantas tindak pidana korupsi, melakukan koordinasi dan konsultasi pengawasan di tingkat daerah serta pembentukan tim penghubung dan tim asistensi, terjadi hambatan peran badan pengawas Mahkamah Agung dalam mewujudkan pemberantasan praktek mafia peradilan di lingkungan pengadilan disebabkan oleh lemahnya badan pengawas untuk membuktikan adanya praktik mafia peradilan tersebut disebabkan rapihnya permainan oknum tersebut dan kebijakan ideal badan pengawas mahkamah agung dalam memberantas praktek mafia peradilan dilakukan dengan cara penal dan non penal yakni penal dengan menggunakan sarana hukum pidana untuk menghukum para pelaku yang terlibat praktek mafia peradilan mulai dari hakim yang menyidangkan perkara sampai panitera. Adapun saran yang dapat disampaikan dalam penelitian ini Sebaiknya mahkamah agung segera berbenah dalam melakukan pengawasan tindakan para oknum mafia peradilan yang berada di lingkungan pengadilan terutama dalam melakukan penegakan hukum yang tidak tebang pilih; dan Sebaiknya agar hakim tidak mudah terbujuk rayu oleh uang suap untuk menangani suatu perkara dan juga menjaga martabat hakim dalam mengadili perkara yang ditangani.

Abstract
The practice of law enforcement in Indonesia
until now is still surrounded by various
problems that keep the law away from its main
purpose to provide justice, certainty, and
benefits to the community. this is due to the
existence of judicial mafia practices that are
difficult to eradicate. The study are focus What
is the policy in the Supreme Court in eradicating


judicial mafia practices within the court Why is there an obstacle in the role of the supreme court supervisory body in realizing the eradication of judicial mafia practices within the court? What is the ideal policy of the Supreme Court supervisory body in eradicating the judicial mafia This study uses a Normative and Empirical Juridical approach. Normative research is carried out on matters that are theoretical principles of law, whereas an empirical approach is carried out to study law in reality in the field. The results of the study found that one of the manifestations of criminal policy efforts in overcoming the practice of judicial mafia in the court environment by building the characteristics of the human resources of the judicial executing instrument that includes Judges and Clerks to become apparatus free from corruption through proven participation in socialization. , Technical guidance and also comparative studies to countries that have the determination to eradicate corruption, conduct Coordination and Supervision Consultation at the Regional Level and Formation of Liaison and Assistance Team, There is an obstacle in the role of the Supreme Court supervisory body in realizing eradication of judicial mafia practices in the court environment due to by the Weak Sectoral Law Enforcement Supervisory Body in each of the Judicial Agencies, Government policies in eradicating judicial corruption are often counterproductive and the ideal Policy of the Court Supervisory Agency great in eradicating the judicial mafia is carried out by means of penal and non-penal namely namely by using criminal law facilities to punish the perpetrators involved in the practice of judicial mafia starting from the judge who hears the case to the court clerk. As for the suggestions that can be conveyed in this study, it is better for the Supreme Court to immediately improve its supervision of the actions of the judicial mafia in the court, especially in conducting law enforcement that is not selective; and It is better that judges are not easily persuaded by bribes to handle a case and also maintain the dignity of the judge in hearing the case being handled. 


\section{A. Pendahuluan}

Undang-Undang Dasar 1945 secara tegas menyatakan bahwa Negara Indonesia berdasarkan atas hukum (rechtsstaat), tidak berdasarkan atas kekuasaan belaka (machtsstaat). ${ }^{1}$ Sebagi sebuah negara hukum (rechtstate) konstitusi Indonesia menjamin persamaan setiap warga negara dihadapan hukum, sebagai salah satu prinsip dasar yang menjadi tuntutan dalam kehidupan berbangsa dan bernegara. ${ }^{2}$ Atas dasar tersebut maka Indonesia juga disebut sebagai negara hukum, dimana negara hukum adalah negara yang sistem penyelenggaraan negaranya didasarkan oleh suatu aturan hukum. Hukum merupakan sebuah kata yang masih abstrak, maka sebagai perwujudannya dengan dikodifikasikannya suatu hukum ke dalam tulisan yang disebut peraturan perundang-undangan. ${ }^{3}$ Dalam mewujudkan tujuan dari Negara Indonesia maka harus diperlukan adanya kesadaran dari semua komponen masyarakat dan pemerintah serta penegak hukum. ${ }^{4}$ Sebagai sarana penegakan hukum Peradilan merupakan suatu sistem atau proses penegakan hukum dan keadilan. Proses memberikan keadilan dilakukan oleh hakim di Pengadilan dengan cara menerima, memeriksa dan memutuskan serta menyelesaikan setiap perkara yang diajukan kepadanya, sesuai dengan aturan hukum acara. ${ }^{5}$ Fungsi ideal pengadilan sebagai institusi penegakan hukum yang bertugas menegakkan hukum dan keadilan, serta menjamin perlindungan hak asasi manusia, pada saat ini mengalami keterpurukan, yang disebabkan karena adanya rekayasa, diskriminatif dan ketidakadilan sebagai hasil korupsi pengadilan (judicial corruption), yang populer disebut mafia pengadilan. ${ }^{6}$ Penegakan hukum yang saat ini diimpikan bagi semua masyarakat yang bertindak fairnes kini makin bergeser saja dengan adanya perbuatan sejumlah oknum memanfaatkan dunia peradilan sebagai ladang untuk mencari keuntungan, padahal fungsi tujuan hukum adalah untuk memberikan kepastian, keadilan dan kemanfaatan. ${ }^{7}$

Praktik penegakan hukum di Indonesia sampai detik ini masih terikat oleh berbagai permasalahan yang menjauhkan hukum dari tujuan utamanya untuk memberikan keadilan, kepastian, dan kemanfaatan bagi masyarak. ${ }^{8}$ Penegakan hukum yang berjalan selama ini terkesan kuat masih berorientasi dalam bentuk keadilan prosedural yang sangat menekankan pada aspek regularitas dan penerapan formalitas legal semata. ${ }^{9}$ Masalah utama penegakan

\footnotetext{
1 Andi Samsuduha, "Perluasan Kewenangan Komisi Yudisial Dalam Rangka Pemberantasan Praktik Mafia Peradilan," Legalitas: Jurnal Hukum, vol.10. No. 2, (December 30, 2018): $247-274$ http://legalitas.unbari.ac.id/index.php/Legalitas/article/view/164. hlm. 248.

${ }^{2}$ Arfan Faiz Muhlizi, "Bantuan Hukum Melalui Mekanisme Nonlitigasi Sebagai Saluran Penguatan Peradilan Informal Bagi Masyarakat Adat (The Legal Aid Through Non Li Ga on Mechanism As Access on Strengthening Informal Jus Ce for Adat Community)," Bantuan Hukum Melalui Mekanisme Nonli Gasi (Arfan Faiz Muhlizi, vol. 2, No. 1, (2013): 65-79, https://rechtsvinding.bphn.go.id/ejournal/index.php/jrv/article/view/82. hlm 66.

${ }^{3}$ Shandi Patria Airlangga, "Hakikat Penguasa Dalam Negara Hukum Demokratis," Cepalo 3, no. 1 (September 17, 2019): 110, https://doi.org/10.25041/cepalo.v3no1.1783. hlm. 2.

${ }^{4}$ Abdul Kholiq and Jurnal Justisi, "Kajian Budaya Hukum Progresif Terhadap Hakim Dalam Penegakan Hukum Pada Mafia Peradilan (Judicial Corruption) Di Indonesia," Justisi Jurnal Ilmu Hukum, vol. 2, No. 1 (2017): 26-44 http://www.merdeka.com/peristiwa/teri.hlm.27

${ }^{5}$ Muhammad Afif et al., "Memberantas Korupsi Melalui Budaya Hukum Yang Baik Dan Cita-Cita Hukum Di Dunia Peradilan Indonesia," Supremasi Jurnal Hukum, Vol. 2, No. 2 (October 2, 2018): 11-21 http://web2.usahid.ac.id/index.php/hukum/article/view/212. hlm 11.

${ }^{6}$ Selamat Widodo, "Diversi Sebagai Bentuk Perlindungan Hak Asasi Anak Yang Berhadapan Dengan Hukum (Studi Di Pengadilan Negeri Purwokerto)," Jurnal Kosmik Hukum, Vol. 17, no. 1 (January 30, 2017): 108-120, https://doi.org/10.30595/kosmikhukum.v17i1.2318.hlm. 108

${ }^{7}$ Abdul Manan, 2005. Penerapan Hukum Acara Perdata di Lingkungan Peradilan Agama. Edisi Revisi. Cet. III. Prenada Media. Jakarta

${ }^{8}$ Suparman, "Menolak Mafia Peradilan: Menjaga Integritas Hakim-Menyelaraskan Perbuatan Dan Nuraninya," Jurnal Hukum \& Pembangunan, vol. 47, No. 1 (accessed July 15, 2020): 61-82, http://www.jhp.ui.ac.id/index.php/home/article/view/135/pdf. hlm. 62.

${ }^{9}$ Bambang Sutiyoso, "Mencari F ormat Ideal Keadilan Putusan dalam Peradilan," Jurnal Hukum IUS QUIA IUSTUM, vol. 17, No. 2 (April 10, 2010): 217-232, http://www.sunan-ampel.ac.id/publicactivity/. hlm. 232.
} 
hukum di negara-negara berkembang khususnya Indonesia adalah bukan pada hukum itu sendiri, melainkan pada kualitas manusia yang menjalankan hukum itu sendiri. ${ }^{10}$ Dunia peradilan kini telah dimanfaatkan oleh sejumlah oknum yang mencari keuntungan semata oleh karena itu mereka disebut mafia peradilan yang merupakan perbuatan yang melawan hukum dan tercela sehingga mengakibatkan hancurnya sendi-sendi keyakinan masyarakat yang menaruh harapan sebagai lembaga yang bisa memberikan keadilan dimata hukum.

Praktik mafia peradilan yang telah merusak integritas citra baik dari pengadilan, dimana telah menempatkan pengadilan seolah-olah menjadi tempat bernaung para mafia yang bisa memainkan hukuman dengan cara melobi para pejabat-pejabat pengadilan untuk mendapatkan sebuah putusan yang ringan atau bebas. Akses kepada keadilan adalah barang yang mahal di Indonesia. Perilaku korup para penegak hukum dan pejabat publik pada lembaga-lembaga penegak hukum menyebabkan hilangnya akses publik untuk memperjuangkan hak-haknya melalui jalur peradilan. ${ }^{11}$ Mafia peradilan atau korupsi peradilan dapat diklasifikasikan sebagai jenis kejahatan yang sukar dijangkau oleh hukum (offences beyond the reach of the law). ${ }^{12}$ Mafia peradilan merupakan bentuk kegagalan peradilan sebagai sarana mencari keadilan, telah menjadi pola tindakan menyimpang dalam proses peradilan pidana. ${ }^{13}$ Dalam presfektif kriminologis, ada banyak faktor yang dapat diidentifikasi sebagai pendorong kondisi timbulnya praktek mafia peradilan, salah satunya dari apparat penegka hukum itu sendiri. ${ }^{14}$ Untuk mencegah agar tidak terjadi lagi praktik mafia peradilan maka dibentuklah Badan Pengawasan Mahkamah Agung. ${ }^{15}$

Badan Pengawasan memiliki tugas dan perannya membantu sekertaris mahkamah agung dalam melaksanakan fungsi pengawasan kinerja di ruang lingkup instansi Mahkamah Agung dan semua badan peradilan dibawahnya. sehingga terjaminnya fungsi pelaksanaan dan pelayanan badan peradilan dalam menegakan hukum dan memberikan keadilan dan kepastian hukum. Berbicara kondisi fakta dilapangan pada saat ini memang tidak dapat dipungkiri bahwa praktik mafia peradilan tersebut sudah merasuki dan merusak semua tatanan struktur hukum dari tingkat atas sampai tingkat bawah. Hal inilah yang menjadi perhatian bagi dunia peradilan pada saat ini, jika dibiarkan merajalela praktik mafia peradilan tersebut dikhawatirkan tidak berfungsinya lagi lembaga peradilan dalam mencari keadilan.

Mafia peradilan menjadi cerminan buruk bagi proses penegakan hukum sehingga praktik ini membuat Indonesia sebagai negara hukum akan terlihat buruk di mata Internasional. Pada hakekatnya dalam perlindungan konstitusional ataupun dalam hukum administratif, perlindungan yang utama terhadap individu terletak pada bagian badan kehakiman yang tegas, bebas dan berani serta yang dihormati. ${ }^{16}$ Merebaknya mafia peradilan seperti ini, kemudian memunculkan gagasan untuk membuka kembali tuntutan terhadap akuntabilitas hakim. Konsep

\footnotetext{
${ }^{10}$ Siswadi Siswadi, "Kedudukan Advokat Sebagai Penegak Hukum Serta Peran Advokat Dalam Proses Hukum Di Sistem Peradilan Pidana Indonesia," IUS CONSTITUTUM, vol. 1, No. 3, (November 10, 2018): 1-37, www.komisihukum.go.id. hlm 3.

${ }^{11}$ Dimas Prasidi, “Akses Publik Terhadap Informasi Di Pengadilan,” Jurnal Konstitusi, vol. 7, No. 3 (May 20, 2016): 161-184, https://jurnalkonstitusi.mkri.id/index.php/jk/article/view/232. hlm 162.

${ }^{12}$ A. Widiada Gunakaya, "Pemberantasan Mafia Peradilan Dengan Pemberdayaan 'Gaya Sentrifugal' Dan 'Sentripetal' Ukum Dalam Penegakan Supremasi Hukum (Suatu Kontemplasi Refleksif),” Jurnal Wawasan Yuridika, vol. 23, No. 2, (October 28, 2014): 167-197, http://ejournal.sthb.ac.id/index.php/jwy/article/view/11. hlm 170.

13 Widodo, "Reformasi Sistem Peradilan Pidana Dalam Rangka Penanggulangan Mafia Peradilan," Jurnal Dinamika Hukum,

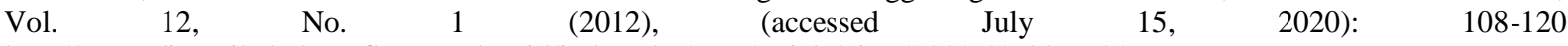
http://www.dinamikahukum.fh.unsoed.ac.id/index.php/JDH/article/view/200/148. hlm 108.

${ }^{14}$ Artidjo Alkostar Masafah et al., "Masalah Mafia Peradilan Dan Penanggulangannya," Jurnal Hukum IUS QUIA IUSTUM, vol. 9, No. 21 (2002): 1-8, https://journal.uii.ac.id/IUSTUM/article/view/4772. hlm 1.

15 Al. Wisnubroto, 1997, Hakim dan Peradilan di Indonesia Dalam Beberapa Aspek Kajian. Yogyakarta: Penerbitan Universitas Atma Jaya,

16. Garry Watuseke, "Eksistensi Hakim Ad Hoc Pada Pengadilan Tindak Pidana Korupsi Dalam Sistem Kekuasaan Kehakiman," LEX ADMINISTRATUM, vol. $5, \quad$ No. $6 \quad$ (October $19, \quad 2017): 15-24$ https://ejournal.unsrat.ac.id/index.php/administratum/article/view/17527. hlm. 17..
} 
yang selalu dipertentangkan dengan independensi hakim. ${ }^{17}$ Keberadaan praktik mafia peradilan menjadi daftar dan rentetan ketidakbecusan negara kita dalam menegakan hukum ditambah lagi praktik korupsi yang sistematis yang belum dapat diberantas sampai sekarang. ${ }^{18}$

Kasus mafia peradilan menjadi pekerjaan rumah sendiri bagi penegak hukum di Indonesia baru-baru ini KPK melakukan penangkapan terhadap hakim di Balikpapan, Kalimantan Timur hakim tersebut terjaring operasi tangkap tangan yang dilakukan oleh KPK. Selain penangkapan tehadap hakim tersebut, terdapat oknum lainnya yang juga dijerat. Berdasarkan info yang didapat kelima oknum tersebut terdiri dari seorang hakim, 2 orang pengacara, beserta seorang panitera dan pihak swasta. Hakim tersebut diindikasikan menerima sejumlah uang untuk menangani kasus di Pengadilan Negeri Balikpapan. KPK juga menyita sejumlah uang dengan nominal Rp 100 juta rupiah. kelima oknum yang ditangkap tersebut kini sedang menjalani pemeriksaan intensif. ${ }^{19}$

Begitulah gambaran mafia peradilan yang melibatkan realitas hakim dan sejumlah oknum lainnya di Indonesia saat ini. Fenomena ini terjadi dikibatkan karena kurangnya integritas moral dan juga nilai-nilai kejujuran serta masih banyaknya orang tergoda dengan iming-iming sejumlah uang demi jual beli perkara. Oleh sebab itu praktik mafia peradilan apabila dibiarkan jelas akan merusak citra moral penegakan hukum di Indonesia dan lebih buruknya negara kita dipandang oleh negara lain sebagai negara yang tidak bisa mempertahankan nilai-nilai luhur dalam penegakan hukum. ${ }^{20}$

Berdasarkan latar belakang tersebut di atas, maka persoalan yang akan dibahas dalam penelitian ini adalah Bagaimanakah kebijakan di Mahkamah Agung dalam pemberantasan praktek mafia peradilan di lingkungan pengadilan? Mengapa terjadi hambatan peran badan pengawas mahkamah agung dalam mewujudkan pemberantasan praktik mafia peradilan di lingkungan pengadilan? Bagaimana kebijakan ideal badan pengawas mahkamah agung dalam memberantas praktek mafia peradilan ?

\section{B. Pembahasan}

\section{Kebijakan di Mahkamah Agung Dalam Pemberantasan Praktek Mafia Peradilan Di Lingkungan Pengadilan}

Berdasarkan wawancara dengan Anwar Usman selaku Ketua Mahkamah Konstitusi Republik Indonesia disalah satu kesempatan seminar nasional beliau mengatakan Salah satu untuk peningkatan Mahkamah Agung dalam menanggulangi dalam pemberantasan praktik mafia peradilan di lingkungan pengadilan salah satunya dengan cara: ${ }^{21}$

\section{a. Peningkatan Kualitas SDM Pada Badan Pengawasan Mahkamah Agung RI}

Sebagai badan pengawasan integral yang membawahi semua peradilan di Indonesia Badan Pengawas Mahkamah Agung mencoba melakukan peningkatan kapasitas manajemen dan juga sumber daya manusia melalui bimbingan teknis (Bimtek) dengan memberikan pemahaman tugas dan fungsi serta kekuatan manajerial dan koordinasi yang baik dalam sistem pengawasan di ruang lingkup Mahkamah Agung. Hal ini guna mencegah terjadinya mafia peradilan di lingkungan badan peradilan sehingga apabila SDM nya mumpuni akan tercipta peradilan yang bersih jauh dari kata KKN.

\footnotetext{
${ }^{17}$ Budi Suhariyanto, "Menuntut Akuntabilitas Putusan Pengadilan Melalui Pemidanaan Terhadap Hakim,” Jurnal Hukum Dan Peradilan 1, no. 2 (July 31, 2012): 249-274, https://doi.org/10.25216/jhp.1.2.2012.249-274. hlm 250.

${ }^{18}$ Ismantoro Dwi Yuwono, 2010, Kisah Para Markus (Makelar Kasus), Media Pressindo, Jakarta, , hlm. 27

${ }^{19} \mathrm{https} / / /$ news.detik.com/berita/d-4535308/kpk-ott-hakim-pn-balikpapan-diduga-suap-untuk-bebaskan-terdakwa,diakses pada Tanggal 7 Mei 2019

${ }^{20}$ Marwan Mas, 2016, Krisis Integritas Hakim, Harian Kompas, Makasar

${ }^{21}$ Berdasarkan wawancara dengan Anwar Usman selaku Ketua Mahkamah Konstitusi Republik Indonesia pada Tanggal 13 April 2019
} 


\section{b. Perjalanan Studi Banding Luar Negeri}

Badan Pengawasan Mahkamah Agung mengadakan studi banding ke negara-negara yang memiliki sistem penegakan hukum yang tegas dalam memberantas para koruptor yakni seperti negara Cina. Dengan adaya hal tersebut diharapkan ketika aparatur penegak hukum di Mahkamah Agung dapat melihat begitu efektifnya sistem hukum negara lain dalam menerapkan pidana mati bagi koruptor sehingga dapat menimbulkan efek jera.

\section{c. Koordinasi dan Konsultasi Pengawasan di Tingkat Daerah}

Sebagai langkah efektif guna melakukan pengawasan Badan Pengawas dapat melakukan kerjasama antar daerah agar terciptanya koordinasi yang baik antar daerah oleh Badan Pengawasan Mahkamah Agung. Menindaklanjuti hal tersebut Badan Pengawasan telah melakukan kegiatan rapat kerja dalam rangka pembinaan/koordinasi dan konsultasi pengawasan dengan para Wakil Ketua, Hakim Tinggi, Panitera/Sekretaris, Panitera Pengganti dan Jurusita. Materi utama dalam pembinaan ini adalah Buku IV tentang Pedoman Pengawasan, Surat Keputusan Ketua Mahkamah Agung RI.No : 076/KMA/SK/VI/2009, Tata cara pemeriksaan audit kinerja dan audit integritas sebagaimana telah ditetapkan berdasarkan Surat Keputusan Ketua Mahkamah Agung RI. No : 42A/BP/SK/IX/2011 tentang Pedoman Audit dan Penilaian Kinerja Integritas Pengadilan, tindak lanjut hasil pemeriksaan pengawas internal dan eksternal serta sosialisasi dalam rangka penyusunan Kode Etik tenaga fungsional non hakim.

\section{d. Kerjasama dengan Komisi Yudisial}

Menurut Aslan Ainin selaku Hakim Pengadilan Negeri Kelas I A Tanjung Karang untuk mencegah terjadinya penyimpangan di badan peradilan ada baiknya memang harus diperbaiki terlebih dahulu mental dan perlaku hakim. Berdasarkan MOU antara Mahkamah Agung dengan lembaga Komisi Yudisial tertanggal 8 April 2009 membentuk suatu tentang Kode Etik dan Pedoman Perilaku Hakim No : 047/KMA/SKB/IV/2009-02/SKB/P.KY/IV/2009 dengan dibentuknya surat keputusan bersama tersebut Komisi Yudisial sebagai lembaga pengawas eksternal bagi penyelenggara kekuasaan kehakiman dapat memantau kode etik dan perilaku hakim yang mana juga didasarkan pada permasalahan bahwa pengawasan internal yang selama ini dilakukan oleh Mahkamah Agung dianggap tidak cukup optimal dan tidak cukup memenuhi prinsip-prinsip akuntabilitas, independensi dan transparansi. ${ }^{22}$

Menurut analisis penulis bahwa apa yang telah disampaikan diatas tidak cukup hanya ditataran tersebut melainkan menurut penulis bahwa terjadinya praktik mafia peradilan tersebut karena adanya oknum yang tidak bertanggungjawab memanfaatkan lembaga peradilan untuk mencari uang yang tidak halal seperti membantu pengurusan perkara dan juga memudahkan menghubungkan antara pejabat pengadilan guna memberikan akses terhadap yang berperkara dan juga birokrasi yang belum menerapkan satu pintu celah inilah yang harus diawasi.

\section{Faktor Terjadi Hambatan Peran Badan Pengawas Mahkamah Agung Dalam Mewujudkan Pemberantasan Praktik Mafia Peradilan Di Lingkungan Pengadilan}

Menurut Ferdy Andrian selaku Jaksa Penuntut Umum pada Kejaksaan Tinggi Lampung apabila ketika melihat fenomena praktik mafia peradilan yang terjadi di Indonesia disebabkan oleh beberapa faktor yang antara lain disebabkan oleh: ${ }^{23}$

\section{a. Tidak Adanya Sikap Jujur dari Para Penegak Hukum}

Belum adanya mentalitas kejujuran dalam proses peradilan turut mendukung tumbuh kembangnya praktik mafia peradilan di lingkungan peradilan. Upaya oknum penegak hukum atau pihak yang berperkara melobi para pihak untuk mendapatkan sebuah keuntungan dengan cara yang tidak lazim seperti menyuap aparat dan juga oknum penegak hukum membebaskan

\footnotetext{
22 Berdasarkan Wawancara Aslan Ainin selaku Hakim Pengadilan Negeri Kelas I A Tanjung Karang Pada Tanggal 12 Maret 2019

${ }^{23}$ Menurut Ferdy Andrian selaku Jaksa Penuntut Umum pada Kejaksaan Tinggi Lampung, Pada Tanggal 24 Agustus 2019
} 
pelaku dari kesalahannya padahal secara fakta unsur-unsur tindak pidananya telah terpenuhi. Dengan dasar pertimbangannya hakim dapat membuat keputusan dari pihak yang salah menjadi pihak yang benar dengan cara menghilangkan unsur-unsurnya hal ini lah yang melahirkan praktik mafia peradilan.

\section{b. Faktor Lingkungan}

Faktor lingkungan turut berperan juga dalam hal seseorang menjadi mafia peradilan. Hal ini tidak dipungkiri kehidupan aparatur yang ingin serba instan dan ingin tampil gaya serta ingin hidup mewah turut membawa sejumlah aparat penegak hukum kedalam lingkaran kejahatan yang mana hal ini akan merangsang seseorang akan berbuat menghalalkan segala cara dan upaya seperti contohnya praktik mafia peradilan. Dengan memanfaatkan pihak berperkara mereka dapat meraih keuntungan untuk sekedar merubah pasal, dakwaan dan tuntutan atau juga putusan hakim.

\section{c. Rapuhnya Mental Para Penegak Hukum}

Memilik jiwa penegak hukum memang tidak mudah banyak sekali seseorang belum siap menjadi penegak hukum karena godaannya begitu besar mulai dari kewenangannya begitu besar sehingga dapat mempengaruhi terhadap perkara yang dipegangnya apakah hal ini dapat dilanjutkan perkaranya atau tidak hal tersebut tergantung otoritas penegak hukum dan juga kehidupan para aparatur penegak hukum yang hidup serba glamour ingin barang-barang yang mewah dan juga ingin mempunyai rekening yang banyak, sehingga apabila dibiarkan seperti itu akan mempengaruhi mentalitas penegak hukum.

Menurut peneliti dari hambatan-hambatan yang ditemui diatas tersebut memang sangat sulit untuk memberantas mafia peradilan di lingkungan peradilan apalagi pada saat sekarang ini karena praktik korupsi sudah sangat meluas dan sudah menjangkiti lembaga peradilan sekalipun. Sebaik-baiknya instrumet dan lembaga hukum yang telah dibuat oleh pemerintah dan mahkamah agung, akan tetapi jika tidak diimbagi oleh political will yang baik dari para pelaksananya hal tersebut jangan diharap untuk mewujudkan penegakan hukum yang bersih di Indonesia, akan tetapi dunia peradilan sekarang sudah semakin baik dari segi administrasinya hal itu dibuktikan sekarang dengan diwujudkannya manajemen satu pintu atau yang disebut Pelayanan Terpadu Satu Pintu (PTSP) sehingga dengan adanya pelayanan satu pintu tersebut dapat meminimalisir praktik pungli dan juga akses untuk bertemunya antara pihak berperkara, Hakim serta Panitera.

\section{Kebijakan Ideal Badan Pengawas Mahkamah Agung dalam Memberantas Praktek Mafia Peradilan}

Menurut Aslan Ainin selaku Hakim Pengadilan Negeri Kelas I A Tanjung Karang Usaha penanggulangn Mafia Peradilan perlu dilakukan kebijakan ideal yang dapat memberantas praktik mafia peradilan tersebut sampai ketingkat akar-akarnya dengan memperbaiki sistem, pengawasan, dan juga manajemen peradilan yang baik akan menciptakan peradilan yang bersih dan bebas dari KKN Maka dalam upaya penanggulangan mafia peradilan dilakukan sebagai berikut:

\section{Upaya Penanggulangan Mafia Peradilan dengan Sarana Penal}

Menyikapi upaya penal dalam pembarantasan praktik mafia peradilan tersebut sudah dibuktikan oleh penegak hukum di Indonesia ini contohnya saja adalah Komisi Pemberantasan Korupsi (KPK). Berdasarkan data Komisi Pemberantasan Korupsi (KPK), sejak 2004 hingga Mei 2018, ada 18 hakim yang pernah ditetapkan sebagai tersangka oleh lembaga tersebut. 
Sebagian yang ditangkap mulai dari hakim konstitusi, hakim tinggi, hingga hakim pada pengadilan negeri. ${ }^{24}$

Penangkapan sejumlah Hakim yang digelar oleh Komisi Pemberantasan Korupsi adalah wujud KPK dalam eksistensinya memberantas tindak pidana korupsi sekaligus mewujudkan kebijakan kriminal dalam rangka menggunakan sarana penal.

\section{Upaya Penanggulangan Mafia Peradilan dengan Sarana Non-Penal}

Menurut Aslan Ainin selaku Hakim Pengadilan Negeri Kelas I A Tanjung Karang Adapun dalam memberantas praktik adanya mafia peradilan di lingkungan pengadilan dengan cara non penal yakni Kebijakan kriminal dengan menggunakan sarana di luar hukum pidana sebagai berikut:

a) Menciptakan birokrasi yang membentengi timbulnya mafia peradilan

Berbicara mengenai konteks birokrasi memang tidak terlepas dari etika pemerintahan dalam merumuskan suatu kebijakan. Perilaku birokrasi yang korup serta tidak diimbangi dengan norma-norma dan tanggungjawab yang baik akan menumbuhkan praktek subur tindakan KKN untuk itu dengan adanya sistem layanan satu pintu sekarang di dalam administrasi peradilan akan mengurangi praktek-praktek KKN tersebut dan juga terbebas dari adanya pungli oleh oknum-oknum yang tidak bertanggungjawab.

b) Mengembangkan substansi penegak hukum yang bermoral dan menggagas budaya hukum

Langkah efektif selanjutnya dalam memberantas mafia peradilan adalah mengembangkan suatu pemahaman moralistik dan juga political will dalam membuat suatu perubahan ditubuh institusi penegak hukum sebagai contohnya dalam hal perekrutan sumber daya manusia di tubuh mahkamah agung harus lah orang-orang yang berkompeten dan jujur hal ini dapat dilihat dari track record hakim dalam menangani suatu perkara apakah selama memegang jabatan hakim tersebut amanah dalam melaksanakan tugasnya ataukah sebaliknya apabila terdapat praktek kecurangan dalam rekam jejaknya maka Mahkamah Agung harus menindak tegas oknum tersebut jika perlu di berhentikan tidak dengan hormat.

Menurut penulis idealnya dalam sebuah lembaga memang sistem pengawasan terhadap lembaga perlu diperketat dan juga harus ada supervisi setiap tahunnya untuk mengevaluasi kinerja-kinerja pegawai pengadilan dan juga jika perlu membentuk sebuah koordinasi secara integral terhadap lembaga lain untuk melakukan sebuah pengintaian dan juga penyadapan terhadap oknnum-oknum yang dicurigai dalam praktik mafia peradilan tersebut sehingga dikedepannya nanti tidak ada lagi praktik jual beli perkara yang akan merusak tatanan sistem hukum dan rusaknya rasa keadilan dalam negeri ini.

\section{Kesimpulan}

Kebijakan di mahkamah agung dalam pemberantasan praktek mafia peradilan di lingkungan pengadilan bahwasannya Mahkamah Agung telah membuat kebijakan tersendiri dalam mencegah terjadinya praktik mafia peradilan dilingkungan pengadilan yakni dengan cara membangun instrument Komisi yudisial dan juga Badan Pengawas Mahkamah Agung, hal tersebut sebagai wujud penegakan hukum yang dilakukan oleh mahkamah agung terhadap unsur pelaksana yang ada di dalam peradilan tersebut seperti hakim dan juga panitera. Salah satu wujud dari upaya kebijakan kriminal dalam menanggulangi praktik mafia peradilan di lingkungan pengadilan dengan cara membangun karakteristik SDM instument pelaksana peradilan yang mencakup Hakim dan juga Panitera agar menjadi aparatur yang bebas dari KKN melalui dibuktikan dengan diikutsertakan melalui sosialisasi, Bimtek dan juga studi banding ke negara yang mempunyai tekad memberantas tindak pidana korupsi, melakukan Koordinasi Dan

24 https://nasional.kompas.com/read/2018/08/29/07241751/daftar-panjang-korupsi-dunia-peradilan-dan-fenomena-hakimtipikor?page=all, Diakses Pada Tanggal 26 Juli 2019 
Konsultasi Pengawasan di Tingkat Daerah serta Pembentukan Tim Penghubung dan Tim Asistensi.

Terjadi hambatan peran badan pengawas mahkamah agung dalam mewujudkan pemberantasan praktek mafia peradilan di lingkungan pengadilan disebabkan oleh Lemahnya badan pengawas penegakan hukum secara sektoral yang ada di masing-masing badan-badan peradilan, Lemahnya badan pengawas sebagaimana dimaksud di atas, karena badan tersebut telah "terkontaminasi" dan ikut tergerus melakukan praktik-praktik korupsi; Lembaga-lembaga masyarakat tidak diberi kesempatan untuk ikut secara langsung mengawasi jalannya peradilan, sehingga dapat diketahui apakah badan-badan peradilan telah menerapkan hukum secara benar dan efektif, Kebijakan pemerintah dalam memberantas korupsi peradilan sering kali kontra produktif, manakala yang terlibat dalam urusan peradilan adalah pejabat pemerintahan yang berasal dari golongan politik tertentu yang sedang berkuasa, Lemahnya kaidah hukum dimafaatkan sebagai peluang untuk melakukan diskresi subyektif dan Tidak diterapkannya sistem peradilan progresif- responsif.

Kebijakan ideal badan pengawas mahkamah agung dalam memberantas praktek mafia peradilan dilakukan dengan cara penal dan non penal yakni penal dengan menggunakan sarana hukum pidana untuk menghukum para pelaku yang terlibat praktik mafia peradilan mulai dari hakim yang menyidangkan perkara sampai panitera.

\section{Daftar Pustaka}

A. Buku

Abdul Manan, 2005. Penerapan Hukum Acara Perdata di Lingkungan Peradilan Agama. Jakarta, Edisi Revisi. Cet. III. Prenada Media.

Al. Wisnubroto, 1997, Hakim dan Peradilan di Indonesia Dalam Beberapa Aspek Kajian. Yogyakarta, Penerbitan Universitas Atma Jaya,

Ismantoro Dwi Yuwono, 2010, Kisah Para Markus (Makelar Kasus), Jakarta, Media Pressindo.

Marwan Mas, 2016, Krisis Integritas Hakim, Makasar, Harian Kompas.

B. Jurnal

Afif, Muhammad, Memberantas Korupsi, Melalui Budaya, and Hukum Yang. "Memberantas Korupsi Melalui Budaya Hukum Yang Baik Dan Cita-Cita Hukum Di Dunia Peradilan Indonesia." Supremasi Jurnal Hukum 1, no. 2, October 2, 2018: 121, http://web2.usahid.ac.id/index.php/hukum/article/view/212.

Airlangga, Shandi Patria. "Hakikat Penguasa Dalam Negara Hukum Demokratis." Cepalo

3, no. 1, September 17, 2019: 1-10. https://doi.org/10.25041/cepalo.v3no1.1783.

Faiz Muhlizi, "Bantuan Hukum Melalui Mekanisme Nonlitigasi Sebagai Saluran

Penguatan Peradilan Informal Bagi Masyarakat Adat (The Legal Aid Through Non

Li Ga on Mechanism As Access on Strengthening Informal Jus Ce for Adat Community)." Bantuan Hukum Melalui Mekanisme Nonli Gasi.... (Arfan Faiz $\begin{array}{llll}\text { Muhlizi. } & \text { Vol. 2013: }\end{array}$ https://rechtsvinding.bphn.go.id/ejournal/index.php/jrv/article/view/82.

Gunakaya, A. Widiada. "Pemberantasan Mafia Peradilan Dengan Pemberdayaan 'Gaya

Sentrifugal' Dan 'Sentripetal' Ukum Dalam Penegakan Supremasi Hukum (Suatu

Kontemplasi Refleksif).” Jurnal Wawasan Yuridika. Vol. 23, October 28, 2014: 167 197, http://ejournal.sthb.ac.id/index.php/jwy/article/view/11.

Kholiq, Abdul, and Jurnal Justisi. "Kajian Budaya Hukum Progresif Terhadap Hakim 
Dalam Penegakan Hukum Pada Mafia Peradilan (Judicial Corruption) Di Indonesia." Justisi Jurnal Ilmu Hukum. Vol. 2, (2017): 26-44, http://www.merdeka.com/peristiwa/teri.

Masafah, Artidjo Alkostar, Mafia Peradilan, Penanggulangannya Masalah, Dan Penanggulangannya, and Artidjo Alkostar. "Masalah Mafia Peradilan Dan Penanggulangannya." Jurnal Hukum IUS QUIA IUSTUM. Vol. 9, 2002: 1-8, https://journal.uii.ac.id/IUSTUM/article/view/4772.

Suparman, "Menolak Mafia Peradilan: Menjaga Integritas Hakim-Menyelaraskan Perbuatan Dan Nuraninya," Jurnal Hukum \& Pembangunan. Accessed July 15, 2020: 161-82, http://www.jhp.ui.ac.id/index.php/home/article/view/135/pdf.

Prasidi, Dimas. “Akses Publik Terhadap Informasi Di Pengadilan.” Jurnal Konstitusi. Vol. $7, \quad$ May 20, 2016: 61-184, https://jurnalkonstitusi.mkri.id/index.php/jk/article/view/232.

Widodo, "Reformasi Sistem Peradilan Pidana Dalam Rangka Penanggulangan Mafia Peradilan." Jurnal Dinamika Hukum. Vol. 12, No. 1 Accessed July 15, 2020: 108120 , http://www.dinamikahukum.fh.unsoed.ac.id/index.php/JDH/article/view/200/148.

Samsuduha, Andi. "Perluasan Kewenangan Komisi Yudisial Dalam Rangka Pemberantasan Praktik Mafia Peradilan." Legalitas: Jurnal Hukum. Vol. 2, $\begin{array}{llll}\text { December } & \text { 240, 2018: }\end{array}$ http://legalitas.unbari.ac.id/index.php/Legalitas/article/view/164.

Siswadi, "Kedudukan Advokat Sebagai Penegak Hukum Serta Peran Advokat Dalam Proses Hukum Di Sistem Peradilan Pidana Indonesia." IUS CONSTITUTUM. Vol. 1, November 10, 2018: 1-37, www.komisihukum.go.id.

Suhariyanto, Budi. "Menuntut Akuntabilitas Putusan Pengadilan Melalui Pemidanaan Terhadap Hakim.” Jurnal Hukum Dan Peradilan 1, no. 2, July 31, 2012: 249-274, https://doi.org/10.25216/jhp.1.2.2012.249-274.

Sutiyoso, Bambang. "Mencari Format Ideal." Jurnal Hukum IUS QUIA IUSTUM. Vol. 17, April 10, 2010: 217-232, http://www.sunan-ampel.ac.id/publicactivity/.

Watuseke, Garry. "Eksistensi Hakim Ad Hoc Pada Pengadilan Tindak Pidana Korupsi Dalam Sistem Kekuasaan Kehakiman.” LEX ADMINISTRATUM. Vol. 5, October 19, 2017:

$15-24$, https://ejournal.unsrat.ac.id/index.php/administratum/article/view/17527.

Widodo, Selamat. "Diversi Sebagai Bentuk Perlindungan Hak Asasi Anak Yang Berhadapan Dengan Hukum (Studi Di Pengadilan Negeri Purwokerto).” Jurnal Kosmik Hukum 17, no. 1, January 30, 2017: 108-120, https://doi.org/10.30595/kosmikhukum.v17i1.2318.

C. Internet

https://news.detik.com/berita/d-4535308/kpk-ott-hakim-pn-balikpapan-diduga-suapuntuk-bebaskan-terdakwa https://nasional.kompas.com/read/2018/08/29/07241751/daftar-panjang-korupsidunia-peradilan-dan-fenomena-hakim-tipikor?page=all 
